\title{
Analysis of selected recurrence risk factors after treatment of head and neck basal cell carcinoma
}

\author{
Mateusz P. Szewczyk ${ }^{1}$, Jakub Pazdrowski ${ }^{1}$, Aleksandra Dańczak-Pazdrowska², Paweł Golusiński ${ }^{1}$, Ewa Majchrzak ${ }^{1}$, \\ Łukasz Łuczewski ${ }^{1}$, Sławomir Marszałek ${ }^{1,3}$, Wojciech Silny ${ }^{4}$, Wojciech Golusiński ${ }^{1}$
}

\author{
${ }^{1}$ Department of Head and Neck Surgery, Poznan University of Medical Sciences, Greater Poland Cancer Centre, Poznan, Poland \\ Head of Department: Prof. Wojciech Golusiński MD, PhD \\ 2Department of Dermatology, Poznan University of Medical Sciences, Poznan, Poland \\ Head of Department: Prof. Zbigniew Adamski MD, PhD \\ ${ }^{3}$ Department of Rehabilitation in Internal Medicine, University School of Physical Education, Poznan, Poland \\ Head of Department: Aleksander Barinow-Wojewódzki Prof. USPE \\ ${ }^{4}$ Great Poland Center of Allergology and Aesthetic Dermatology "Art Clinic", Poznan, Poland \\ Head of Department: Prof. Wojciech Silny MD, PhD
}

Postep Derm Alergol 2014; XXXI, 3: 146-151

DOI: $10.5114 /$ pdia.2014.40959

\begin{abstract}
Introduction: Basal cell carcinoma (BCC) is the most common type of non-melanoma malignant skin tumors. Eighty-five percent of all cases are located on the skin of the head and neck. The risk of recurrence after surgery is estimated at $5-15 \%$.

Aim: To evaluate the selected risk factors for recurrence after surgical treatment of head and neck BCC at the Department of Head and Neck Surgery in the Greater Poland Cancer Centre of the Poznan University of Medical Sciences. Material and methods: A retrospective analysis was made of patients treated at the Department of Head and Neck Surgery in the Greater Poland Cancer Centre of the Poznan University of Medical Sciences in 2007-2012 for BCC of the head and neck region. The study covered 312 patients: 198 males (63\%) and 114 females (37\%), aged 32-96 years. Results: In the study group of 312 tumors, recurrence after initial treatment in this Centre was diagnosed in 18 patients $(9 \%)$, whereas in patients who were previously operated elsewhere, recurrence was found in 22 cases $(17 \%)$. The nodular type was the most common BCC type in the study group and concerned 175 patients (56\%). The most numerous group $(114 ; 37 \%)$ in this study group comprised patients with external nose and cheek tumors.

Conclusions: The importance of preoperative biopsy to assess the histological type as a routine treatment of patients with BCC is essential. Ultrasound evaluation to assess the exact size and depth of tumor invasion should also be implemented.
\end{abstract}

Key words: basal cell carcinoma, recurrence, surgery.

\section{Introduction}

Basal cell carcinoma (BCC) is the most common non-melanoma malignant skin tumour [1, 2]. It originates from the epidermal or progenitor cells of the hair follicle, which resemble the basal cell layer of the epidermis. The cancer is characterized by a high local malignancy and a high (tenfold) risk of a second primary cancer to occur [3]. Histologically, it is divided into nodular, superficial, morpheaform, infiltrative or mixed types (Table 1).

Eighty-five percent of BCC cases are located on the skin of the head and neck [4], which results from the exposure to UV sunshine, the main risk factor [5]. Other risk factors include radiotherapy and immunosuppression (risk being 10 to 20 times higher in patients after organ transplants) [6-9].

Basal cell carcinoma is the most commonly diagnosed cancer in the world. The BCC prevalence is constantly growing, which may likely be caused by increased UV radiation associated with destruction of the ozone layer, increased outdoor physical activity and dress code changes [10]. The geographical distribution of BCC incidence is, above all, conditioned by the duration of sunshine exposure. The highest incidence occurs in Australia (1041 per 100,000 population in males and 745 per

Address for correspondence: Mateusz P. Szewczyk MD, PhD, Department of Head and Neck Surgery, Poznan University of Medical Sciences, Greater Poland Cancer Centre, 15 Garbary St, 61-866 Poznan, Poland, phone: +48 6188509 28, e-mail: mateuszszewczyk@yahoo.pl Received: 14.11.2013, accepted: 4.12.2013. 
Table 1. Basal cell carcinoma characteristics

\begin{tabular}{ll}
\hline Nodular & Microscopic characteristics: clusters of cancerous cells of different size and shape, showing a palisade-like \\
& arrangement at the circumference \\
& Location: head and neck \\
& Risk factor: UV exposure \\
& Note: the most common histological type \\
\hline Superficial & Microscopic characteristics: irregular clusters of cancer cells attached to atrophic epidermis, rarely penetrating \\
& down into the dermis \\
& Location: trunk \\
& Risk factor: intensive short exposure to sunshine \\
& Notes: more commonly diagnosed in women and young people \\
\hline Morpheaform & Microscopic characteristics: strips of atypical basaloid cells sunk in a thick fibrous bed \\
& Location: head and neck \\
& Risk factor: UV exposure \\
& Note: represents approximately $6 \%$ of all BCC cases, very aggressive growth \\
& Microscopic characteristics: atypical basaloid cells arranged in several layers of thick longitudinal strips without \\
circumferential palisade-form cells \\
Location: head and neck \\
Risk factor: prolonged UV exposure \\
Note: represents approximately $4.8 \%$ of all BCC cases, aggressive growth
\end{tabular}

100,000 population in females) versus Germany, a country of the lowest incidence (53 per 100,000 population in males and 46 per 100,000 in females) [11]. In Poland, BCC incidence is estimated at 69.8 per 100,000 population [12].

In the United States, the total number of BCC and squamous cell carcinoma (SCC) of the skin (ratio $3: 1$ ) is higher than the number of all other cancers. One in three cancers diagnosed in the world is skin cancer [13]. The incidence of BCC is still increasing. It has tripled in the last 30 years [14]. Vries et al. [15] reports an expected increased incidence of BCC to be maintained at least until 2015.

Over the two recent decades, the mean age of BCC patients decreased as sun bed tanning has been more and more popular with young people [16].

The risk of recurrence after surgery is estimated at 5-15\%. It depends, among other things, on the severity of the disease, its location, histological type of tumor and surgical technique primarily used [17]. The BCC treatment approaches include wide surgical resection, Mohs micrographic surgery, radiotherapy, photodynamic therapy, local treatment (e.g. imiquimod), cauterization and cryotherapy [1]. It is believed, however, that classic surgical excision should be the gold standard for the treatment of basal cell carcinoma of the head and neck, especially when radical resection is possible.

\section{Aim}

The aim of this study is to evaluate the selected risk factors for recurrence after surgical treatment of head and neck basal cell carcinomas at the Department of Head and Neck Surgery in the Greater Poland Cancer Centre of the University of Medical Sciences in Poznan.

\section{Material and methods}

A retrospective analysis was made of patients treated at the Department of Head and Neck Surgery in the Greater Poland Cancer Centre of the Poznan University of Medical Sciences in 2007-2012 for basal cell carcinoma of the head and neck region. The study included 312 patients: 198 males (63\%) and 114 females (37\%), aged 32-96 years (median age 73 years) (Table 2 ).

\section{Results}

Results are presented in Tables $3-10$. In the study group of 312 tumors, 204 (65\%) were patients with pri-

Table 2. Patient characteristics $(n=312)$

\begin{tabular}{|c|c|c|c|c|c|c|c|}
\hline \multirow[t]{2}{*}{ Variables } & \multicolumn{7}{|c|}{ Tumor location } \\
\hline & Nose and cheek & Auricle & Lips and chin & Ocular & Scalp & Forehead & Total \\
\hline No. of patients & $114(37 \%)$ & $82(26 \%)$ & $52(17 \%)$ & $36(12 \%)$ & $18(6 \%)$ & $8(3 \%)$ & $312(100 \%)$ \\
\hline Female & $46(41 \%)$ & $21(26 \%)$ & $29(44 \%)$ & $14(39 \%)$ & $2(12 \%)$ & $2(25 \%)$ & $114(37 \%)$ \\
\hline Male & $68(59 \%)$ & $61(74 \%)$ & $25(46 \%)$ & $22(61 \%)$ & $16(88 \%)$ & $6(75 \%)$ & $198(63 \%)$ \\
\hline Patients in primary treatment & $72(63 \%)$ & $62(75 \%)$ & $40(77 \%)$ & $16(44 \%)$ & $8(44 \%)$ & $4(50 \%)$ & $204(65 \%)$ \\
\hline Patients in recurrence treatment & $42(37 \%)$ & $20(25 \%)$ & $12(23 \%)$ & $20(56 \%)$ & $10(66 \%)$ & $4(50 \%)$ & $108(35 \%)$ \\
\hline Mean follow-up [months] & 57 & 27 & 22 & 19 & 28 & 26 & \\
\hline
\end{tabular}


M.P. Szewczyk, J. Pazdrowski, A. Dańczak-Pazdrowska, P. Golusiński, E. Majchrzak, Ł. Łuczewski, S. Marszałek, W. Silny, W. Golusiński

Table 3. The BCC classification according to TNM - all patients

\begin{tabular}{cccccccc}
\hline & Nose and cheek & Auricle & Lips and chin & Ocular & Scalp & Forehead & Total \\
\hline T1 & $27(24 \%)$ & $24(30 \%)$ & $21(39 \%)$ & $7(19 \%)$ & 0 & 0 & $79(25 \%)$ \\
\hline T2 & $32(28 \%)$ & $39(47 \%)$ & $11(20 \%)$ & $18(50 \%)$ & $2(11 \%)$ & $2(25 \%)$ & $104(33 \%)$ \\
\hline T3 & $36(32 \%)$ & $16(20 \%)$ & $15(28 \%)$ & $6(17 \%)$ & $12(77 \%)$ & $4(50 \%)$ & $89(28 \%)$ \\
\hline T4 & $19(16 \%)$ & $3(3 \%)$ & $7(13 \%)$ & $5(14 \%)$ & $4(22 \%)$ & $2(25 \%)$ & $40(14 \%)$ \\
\hline All & $114(100 \%)$ & $82(100 \%)$ & $54(100 \%)$ & $36(100 \%)$ & $18(100 \%)$ & $8(100 \%)$ & $312(100 \%)$ \\
\hline
\end{tabular}

Table 4. BCC classification according to TNM - recurrences

\begin{tabular}{cccccccc}
\hline & Nose and cheek & Auricle & Lips and chin & Ocular & Scalp & Forehead & All \\
\hline T1 & $2(9 \%)$ & $1(12 \%)$ & 0 & 0 & 0 & 0 & $3(7.5 \%)$ \\
\hline T2 & $8(35 \%)$ & $2(22 \%)$ & 0 & $1(25 \%)$ & 0 & $1(100 \%)$ & $12(30 \%)$ \\
\hline T3 & $7(30 \%)$ & $4(44 \%)$ & $1(100 \%)$ & $1(25 \%)$ & $1(50 \%)$ & 0 & $14(35 \%)$ \\
\hline T4 & $6(26 \%)$ & $2(22 \%)$ & 0 & $2(50 \%)$ & $1(50 \%)$ & 0 & $11(27.5 \%)$ \\
\hline All & $23(100 \%)$ & $9(100 \%)$ & $1(100 \%)$ & $4(100 \%)$ & $2(100 \%)$ & $1(100 \%)$ & $40(100 \%)$ \\
\hline
\end{tabular}

Table 5. BCC histological types - all patients

\begin{tabular}{lccccccc}
\hline & Nose and cheek & Auricle & Lips & Ocular & Scalp & Forehead & All \\
\hline Nodular & $68(60 \%)$ & $44(54 \%)$ & $28(52 \%)$ & $21(59 \%)$ & $10(55 \%)$ & $4(50 \%)$ & $175(56 \%)$ \\
\hline Superficial & $4(4 \%)$ & $5(6 \%)$ & $10(19 \%)$ & $4(11 \%)$ & $2(11 \%)$ & 0 & $25(8 \%)$ \\
\hline Morpheaform & $14(12 \%)$ & $11(13 \%)$ & $5(9 \%)$ & $5(14 \%)$ & $1(6 \%)$ & $2(25 \%)$ & $38(12 \%)$ \\
\hline Infiltrative & $11(10 \%)$ & $4(5 \%)$ & $7(13 \%)$ & $3(8 \%)$ & $3(17 \%)$ & $1(12.5 \%)$ & $29(9 \%)$ \\
\hline Mixed & $17(14 \%)$ & $18(22 \%)$ & $4(7 \%)$ & $3(8 \%)$ & $2(11 \%)$ & $1(12.5 \%)$ & $45(15 \%)$ \\
\hline All & $114(100 \%)$ & $82(100 \%)$ & $54(100 \%)$ & $36(100 \%)$ & $18(100 \%)$ & $8(100 \%)$ & $312(100 \%)$ \\
\hline
\end{tabular}

Table 6. Treatment results - local recurrence by location

\begin{tabular}{lccccccc}
\hline Location & Nose and cheek & Auricle & Lips and chin & Ocular & Scalp & Forehead & Total \\
\hline $\begin{array}{l}\text { Recurrence after primary } \\
\text { treatment }\end{array}$ & $11(15 \%)$ & $5(8 \%)$ & 0 & $1(6 \%)$ & $1(12.5 \%)$ & 0 & $18(9 \%)$ \\
\hline $\begin{array}{l}\text { Recurrence after recurrence } \\
\text { treatment }\end{array}$ & $12(23 \%)$ & $4(16 \%)$ & $1(8 \%)$ & $3(14 \%)$ & $1(10 \%)$ & $1(25 \%)$ & $22(17 \%)$ \\
\hline
\end{tabular}

Table 7. Treatment results - local recurrence by location and gender

\begin{tabular}{lccccccc}
\hline & Nose and cheek & Auricle & Lips and chin & Ocular & Scalp & Forehead & All together \\
\hline Female & 46 & 21 & 29 & 14 & 2 & 2 & 114 \\
\hline Recurrence & 8 & 3 & 0 & 1 & 0 & 0 & $12(10 \%)$ \\
\hline Male & 68 & 61 & 25 & 22 & 16 & 6 & 198 \\
\hline Recurrence & 15 & 6 & 1 & 3 & 2 & 1 & $28(14 \%)$ \\
\hline
\end{tabular}

Table 8. Treatment results - local recurrence after primary treatment by BCC histological type

\begin{tabular}{lccccccc}
\hline & Nose and cheek & Auricle & Lips and chin & Ocular & Scalp & Forehead & All \\
\hline Nodular & 5 & 1 & 0 & 0 & 1 & 0 & 7 \\
\hline Superficial & 0 & 0 & 0 & 0 & 0 & 0 & 0 \\
\hline Morpheaform & 3 & 2 & 0 & 0 & 0 & 0 & 5 \\
\hline Infiltrative & 2 & 2 & 0 & 1 & 0 & 0 & 5 \\
\hline Mixed & 1 & 0 & 0 & 0 & 0 & 0 & 1 \\
\hline All & 11 & 5 & 0 & 1 & 1 & 0 & 18 \\
\hline
\end{tabular}


Table 9. Treatment results - local recurrence after recurrence treatment by BCC histological type

\begin{tabular}{lccccccc}
\hline & Nose and cheek & Auricle & Lips and chin & Ocular & Scalp & Forehead & All \\
\hline Nodular & 5 & 1 & 0 & 1 & 1 & 0 & 9 \\
\hline Superficial & 1 & 0 & 0 & 0 & 0 & 0 & 1 \\
\hline Morpheaform & 3 & 1 & 1 & 1 & 0 & 0 & 6 \\
\hline Infiltrative & 2 & 2 & 0 & 1 & 0 & 1 & 6 \\
\hline Mixed & 0 & 0 & 0 & 0 & 0 & 0 & 0 \\
\hline All & 12 & 4 & 1 & 3 & 1 & 1 & 22 \\
\hline
\end{tabular}

marily diagnosed basal cell carcinoma, while the other 108 (35\%) presented for treatment with a recurrence of the disease. After initial treatment in this clinic, recurrence was diagnosed in 18 patients (9\%), whereas in patients who were previously operated elsewhere, recurrence was found in 22 cases (17\%).

Of the 312 patients, 114 were women (37\%) in whom, after surgical treatment, 12 recurrences (10\%) were diagnosed. Among the 198 males (63\%), recurrence after treatment was found in 28 cases (14\%) (Table 7).

In 278 cases (89\%), the surgical specimen was removed by conventional surgery. In this group tumor recurrence was diagnosed in 38 patients (14\%). $\mathrm{CO}_{2}$ laser was used in 34 patients (11\%), followed by a relapse of two of them (6\%) (Table 10).

The nodular type was the most common basal cell carcinoma type in the study group and concerned 175 patients (56\%). Recurrence was observed in 16 of them (40\%). The second most common type was a mixed type (45 patients $(15 \%)$, one recurrence $(2 \%))$. Further types were the morpheaform (38 patients (12\%), 11 relapses (28\%)); infiltrative (29 patients (9\%), 11 recurrences $(28 \%)$ ) and superficial type (25 patients ( $8 \%)$, one recurrence $(2 \%)$ ).

Seventy-nine patients (25\%) were referred to our institution in stage T1 tumor according to TNM classification, 104 (33\%) in stage T2, 89 (28\%) in stage T3 and 40 patients (14\%) in stage T4. Stage T3 tumors were most associated with tumor recurrence (14 patients; 35\%), followed successively by T4 (12 patients; 30\%), T2 (11 patients; $27.5 \%$ ) and T1 (3 patients; 7.5\%) (Tables 5, 8 and 9).

The most numerous group $(114 ; 37 \%)$ in our study group were patients suffering from basal cell carcinoma of the external nose and cheek. A local recurrence of BCC was found in 11 patients (15\%) who received primary treatment (pBCC) and a second recurrence was found in $12(23 \%)$ patients treated due to the recurrence ( $\mathrm{rBCC}$ ). The mean follow-up time was 57 months (Table 5). Of 82 patients with auricle tumors, a local cancer recurrence was observed in $5(8 \%)$ cases, rBCC in 4 patients $(16 \%)$ (follow-up was 17 months) (Table 5). Of 52 patients with primary BCC of the lip and chin region, none was found to have a local recurrence. Of the 36 (12\%) patients with tumor in the ocular region, a recurrence after primary treatment was found in one case, rBCC in 3 cases (14\%). Among the 18 patients (6\%) with scalp tumor, a recur-
Table 10. Treatment results - local recurrence by surgical technique used

\begin{tabular}{lccc}
\hline & Classic surgery & $\mathrm{CO}_{2}$ Laser & All \\
\hline Cases & 278 & 34 & 312 \\
\hline Recurrence & 38 & 2 & 40 \\
\hline \% of recurrences & 14 & 6 & 13 \\
\hline
\end{tabular}

rence after primary treatment was diagnosed in $1 \mathrm{pa}$ tient, after secondary treatment also in 1 patient (Table 5). The smallest group consisted of patients with forehead BCC (8 patients, 3\%). A relapse was found in 1 patient with a previously diagnosed recurrence.

\section{Discussion}

Basal cell carcinoma is the most common cancer among Caucasians characterized by high local malignancy, and also a high rate of recurrence. Therefore, it is a significant social problem. For this reason, the authors undertook the analysis of selected risk factors for recurrence after treatment of BCC.

Analysis of 312 patients diagnosed with BCC of the head and neck was conducted. Of these, 204 (65\%) patients were patients with primary BCC (pBCC), and 108 patients (35\%) were referred from other centers with a diagnosis of recurrent $B C C$ ( $r B C C)$. In this study, a recurrence after surgery of $\mathrm{rBCC}$ was found in 22 patients, representing $17 \%$ of the total group of patients operated due to the recurrence. This result is inferior compared to patients treated primarily (18 cases, 9\%). According to the literature, previously treated $\mathrm{BCC}$ is a strong risk factor for subsequent relapses. Sartore et al. [17] reported a $23 \%$ recurrence rate in patients previously treated versus $18 \%$ in patients who have not been treated before. Similar results were reported by Sliverman et al. [18] (11.6\% in a group of 135 patients). In their publication, Rowe et al. [19] showed the recurrence incidence of $17.4 \%$ for patients after rBCC surgery.

The head and neck BCC incidence rate is higher in men due to a more extensive exposure to sunshine. Women, on the other hand, tend more to use clothes covering the head and neck region. The above gender-specific distribution of the disease is reflected in publications by Yaldiz et al. [20] and Bastiaens et al. [21] where men accounted 
for $62.8 \%$ and $54 \%$ of cases, respectively. Similarly in our study, men represented the majority of the population (198 patients, 63\%). The male : female ( $M$ : F) rate was $1.74: 1$. In contrast, Zhang et al. [22] found a $M:$ F rate of $1: 1.1$, but their study group consisted of 60 cases only. In this study, the local recurrence rate in the female population was estimated at 10\% (12 patients). In men, the number of treatment failures was 28 , that is $14 \%$. More favorable treatment results in women may be accounted for by their taking more care of their looks and seeking medical aid earlier. Sartore et al. [17], contrary to the above correlation, did not demonstrate in their report any relationship between gender and incidence of the basal cell carcinoma recurrence.

Classical surgery with intraoperative microscopic assessment of margins is a gold standard in treatment of head and neck basal cell carcinomas. This is due to high efficacy and low cost of the procedure [23]. We do not perform Mohs surgeries in our centre. However, Mosterd et al. [24] demonstrated that although the incidence of local recurrences after treatment using conventional surgical techniques is higher than in the Mohs method, the difference is not statistically significant. In this study after classical surgical resection, 38 recurrences were noted, both for patients presenting with primary $\mathrm{BCC}(\mathrm{pBCC})$ and recurrent BCC (rBCC), constituting a 14\% recurrence rate for procedures performed in that fashion. In contrast, a cancer recurrence in the 34 patients treated with $\mathrm{CO}_{2}$ laser was found in 2 patients (a $6 \%$ recurrence rate). lyer et al. [25] showed a recurrence rate of $3.2 \%$ in their group of 61 patients treated using laser techniques.

The most commonly diagnosed histological type of BCC at the Greater Poland Cancer Centre was the nodular type (175 patients, 56\% of all cases), followed by the mixed type $(45 ; 15 \%)$, morpheaform type $(38 ; 12 \%)$ and infiltrative type $(29 ; 9 \%)$. Our results are in good agreement with the analyses by Bastiaens et al. [21] (1280 nodular types out of 1960 specimens studied) and Betti et al. [26] (1008/1774). Seven cases (39\%) of the local recurrence after primary treatment of BCC nodular type were found. This number is inferior to recurrences after infiltrative and morpheaform BCC types ( 5 and 5 patients, respectively; 55\%). Considering a lower number of patients with originally diagnosed infiltrative and morpheaform BCC subtypes, these should be assumed to be characterized by a stronger tendency to relapse. With regard to treatment of patients presenting with recurrent BCC, the proportions of the above subtypes were similar (9 patients; (40\%), 6 and 6 patients, respectively $(54 \%))$. Our results are consistent with reports by Bartos et al. [27], who showed that 54\% of all recurrences in their study sample were more aggressive subtypes. Sartore et al. [17] also identified the highest proportion of local failures to occur in patients with infiltrative and morpheaform BCC.
In terms of the stage of the disease, the largest group presenting was formed by patients with stage T2 tumors (104; 33\%). On the other hand, patients with stage T3 (14; 35\%) and T4 (12; 30\%) had the highest incidence of tumor recurrence. It is postulated that the larger size tumors may make consistent effective radical surgical excision more difficult.

The most numerous group of BCC patients treated in this Centre were those suffering from basal cell carcinoma of the external nose and cheek. The second in order were patients with BCC of the auricle (82 cases; $26 \%$ ). In the study by Janjua et al. [28], patients with tumors of the nose and cheek region also represented a clear majority (97 cases out of 171 patients). Similar results were reported by Chow et al. [29], Aandani and Ganatra [30]. As in the reports by Ocanha et al. [31] and Farhi et al. [32], this study found the highest number of local recurrences following primary surgical treatment for tumors of the nose and cheek (11 cases; $15 \%$ ) and auricle (5 patients; $8 \%)$. This is most likely caused by the complex anatomy of those regions and consequent difficulty in achieving sufficient radicality of the procedure.

In conclusion, BCC is characterized by a high risk of recurrence, which should lead to careful treatment planning. In order to improve the results of treatment, preoperative evaluation using high-frequency ultrasound (HF USG) could be implemented in the assessment of the depth of the tumor infiltration. A reliably useful correlation between the size of the tumor assessed by USG and histopathological examination has been demonstrated [33]. Preoperative biopsy with histopathological evaluation may lead to a wider extension of free surgical margins when histological type suggesting a greater risk of recurrence (invasive, morpheaform) is found. Similarly, wider free margins in excising the tumor should be applied when treating the recurrence. More cautious and hence, wider margins must also be incorporated for lesions located in the nose and cheek region. Periodic and long-term follow up is extremely important not only to assess the occurrence of a possible relapse, but also to address the fact that patients with BCC are at an increased risk of developing a second primary lesion.

Certain limitations of this study are present. The authors analyzed only some of the risk factors. In the evaluation of the recurrence risk other factors may be important such as the degree of sun exposure in childhood, alcohol and tobacco abuse, profession, treatment with immunosuppressive drugs and many others, which were not analyzed. It should be noted that a number of risk factors in one patient could potentially multiply the risk of recurrence - no such analysis has been performed.

\section{Conclusions}

An important clinical problem in the treatment of basal cell skin cancer of the head and neck region is the 
high percentage of local failures. The importance of preoperative biopsy to assess the histological type as a routine treatment of patients with BCC is essential. Ultrasound evaluation to assess the exact size and depth of tumor invasion should also be implemented. Regular and systematic check-ups at specialized outpatient clinics are very important. The authors propose a scheme every 6 months during the first year after surgery and then every 12 months or in the event of an alarming lesion.

\section{Conflict of interest}

None declared.

\section{References}

1. Baxter JM, Patel AN, Varma S. Facial basal cell carcinoma. BMJ 2012; 345: e5342.

2. Sobjanek M, Michajłowski I, Malek M, et al. Skin cancer in the elderly - epidemiological, clinical and surgical treatment analysis of 254 patients. Postep Derm Alergol 2012; 29: 40710.

3. Faurschou A, Wulf HC. Ecological analysis of the relation between sunbeds and skin cancer. Photodermatol Photoimmunol Photomed 2007; 23: 120-5.

4. Rubin Al, Chen EH, Ratner D. Basal-cell carcinoma. N Engl J Med 2005; 353: 2262-9.

5. Pazdrowski J, Dańczak-Pazdrowska A, Golusiński P, et al. The recurrence of facial basal cell carcinoma in patients treated at the Head and Neck Surgery Ward and Laryngological Oncology Clinic of the Greater Poland Cancer Centre in the years 2007-2010. Otolaryngol Pol 2012; 66: 185-90.

6. Watt TC, Inskip PD, Stratton K, et al. Radiation-related risk of basal cell carcinoma: a report from the Childhood Cancer Survivor Study. J Natl Cancer Inst 2012; 104: 1240-50.

7. Tessone A, Amariglio N, Weissman O, et al. Radiotherapy-induced basal cell carcinomas of the scalp: are they genetically different? Aesthetic Plast Surg 2012; 36: 1387-92.

8. Witmanowski H, Lewandowska M, Szychta P, et al. The development of squamous cell carcinoma in a patient after kidney transplantation: a case report. Postep Derm Alergol 2013; 30: 65-71.

9. Mańkowski B, Osmola-Mańkowska A, Olszański R, et al. Squamous cell carcinoma as a long-term effect after skin vascular malformation radiotherapy. Postep Derm Alergol 2012; 29: 471-4.

10. Gloster HM Jr, Brodland DG. The epidemiology of skin cancer. Dermatol Surg 1996; 22: 217-26.

11. Lomas A, Leonardi-Bee J, Bath-Hextall F. A systematic review of worldwide incidence of nonmelanoma skin cancer. $\mathrm{Br}$ J Dermatol 2012; 166: 1069-80.

12. Wojciechowska U, Didkowska J, Zatoński W. Nowotwory złośliwe w Polsce w 2010 roku [Polish]. Warsaw 2012.

13. Tan S, Sinclair C, Foley P. Running behind tourist leisurerelated skin cancer prophylaxis. Br J Dermatol 2012; 167 Suppl 2: 70-5.

14. Staples MP, Elwood M, Burton RC, et al. Non-melanoma skin cancer in Australia: the 2002 national survey and trends since 1985. Med J Aust 2006; 184: 6-10.

15. De Vries E, Louwman M, Bastiens M, et al. Rapid and continous increases in incidence rates of basal cell carcinomain the southwest Netherlands since 1973. I Invest Dermatol 2004; 123: 634-8.
16. Faurschou A, Wulf HC. Ecological analysis of the relation between sunbeds and skin cancer. Photodermatol Photoimmunol Photomed 2007; 23: 120-5.

17. Sartore L, Lancerotto L, Salmaso M, et al. Facial basal cell carcinoma: analysis of recurrence and follow-up strategies. Oncology Reports 2011; 26: 1423-9.

18. Silverman MK, Kopf AW, Bart RS, et al. Recurrence rates of treated basal cell carcinomas. Part 3: Surgical excision. J Dermatol Surg Oncol 1992; 18: 471-6.

19. Rowe D, Gallagher RP, Warshawski L, Carruthers A. Females vastly outnumber males in basal cell carcinoma of the upper lip. A peculiar subset of high risk young females is described. J Dermatol Surg Oncol 1994; 20: 754-6.

20. Yaldiz M, Uzuniar AK, Buyukbayram H. Histopatologic features of the 460 basal cell carcinomas cases. J Med Sci 1999; 19: 249-54.

21. Bastiaens MT, Hoefnagel JJ, Bruijn JA, et al. Differences in age, site distribution, and sex between nodular and superficial basal cell carcinoma indicate different types of tumors. J Invest Dermatol 1998; 110: 880-4.

22. Zhang B, Wang N, He W. Clinicopathologic analysis of 60 cases of basal cell carcinoma. Chin Med Sci J 1993; 8: 121-2.

23. Avril MF, Auperin A, Margulis A, et al. Basal cell carcinoma of the face: surgery or radiotherapy? Results of a randomized study. Br J Cancer 1997; 76: 100-6.

24. Mosterd K, Krekels GA, Nieman FH, et al. Surgical excision versus Mohs' micrographic surgery for primary and recurrent basal-cell carcinoma of the face: a prospective randomised controlled trial with 5-years' follow-up. Lancet Oncol 2008; 9: 1149-56.

25. Iyer S, Bowes L, Kricorian G, et al. Treatment of basal cell carcinoma with the pulsed carbon dioxide laser: a retrospective analysis. Dermatol Surg 2004; 30: 1214-8.

26. Betti R, Radaelli G, Bombonato C, et al. Anatomic location of basal cell carcinomas may favor certain histologic subtypes. J Cutan Med Surg 2010; 14: 298-302.

27. Bartoš V, Pokorný D, Zacharová O, et al. Recurrent basal cell carcinoma: a clinicopathological study and evaluation of histomorphological findings in primary and recurrent lesions. Acta Dermatovenerol Alp Panonica Adriat 2011; 20: 67-75.

28. Janjua OS, Qureshi SM. Basal cell carcinoma of the head and neck region: an analysis of 171 cases. J Skin Cancer 2012; 2012: 943472.

29. Chow VL, Chan JY, Chan RC, et al. Basal cell carcinoma of the head and neck region in ethnic Chinese. Int I Surg Oncol 2011; 2011: 890908.

30. Aandani A, Ganatra A. Incidence of basal cell carcinoma at plastic surgery department of tertiary care hospital in Karachi. J Surg Pakistan 2011; 27: 117-20.

31. Ocanha JP, Dias JT, Miot HA, et al. Relapses and recurrences of basal cell face carcinomas. An Bras Dermatol 2011; 86: 386-8.

32. Farhi D, Dupin N, Palangié A, et al. Incomplete excision of basal cell carcinoma: rate and associated factors among 362 consecutive cases. Dermatol Surg 2007; 33: 1207-14.

33. Polańska A, Dańczak-Pazdrowska A, Silny W, et al. High-frequency ultrasonography in monitoring the effects of treatment of selected dermatoses. Postep Derm Alergol 2011; 28: 255-60. 